\title{
Determination of reference values for cytokines and matrix metalloproteinases in the synovial fluid of horses of different ages
}

\author{
Maria A. Chiappe Barbará ${ }^{1}$, Gustavo Perrone ${ }^{2}$, Nicolás Caggiano ${ }^{1}$, \\ Yael Lastra', Florencia Rubatino ${ }^{1}$, Araceli Ferretto ${ }^{1}$, \\ and Emilio A. De Simone ${ }^{1 *}$
}

${ }^{1}$ Animal Physiology Chair, School of Veterinary Sciences, Buenos Aires University, Buenos Aires, Argentina

${ }^{2}$ Equine Production Chair, School of Veterinary Sciences, Buenos Aires University, Buenos Aires, Argentina

\begin{abstract}
CHIAPPE BARbARÁ, M. A., G. PERRONe, N. CAGgiAnO, Y. LASTRA, F. RUBATINO, A. FERRETTO, E. A. DE SIMONE: Determination of reference values for cytokines and matrix metalloproteinases in the synovial fluid of horses of different ages. Vet. arhiv 88, 159-170, 2018.
\end{abstract}

\section{ABSTRACT}

Osteoarthritis $(\mathrm{OA})$ is the most common joint disease in sport horses. Inflammatory and anti-inflammatory cytokines and metalloproteinases (MMPs) play a crucial role in the degradation of the cartilage extracellular matrix. The study of inflammatory molecular biomarkers could be useful in the diagnosis and choice of therapeutic strategies. However, little is known about the normal values of inflammatory biomarkers at different ages. Moreover, early diagnosis of OA is crucial to ensure early treatment in order to prevent chronic damage. The aim of this study was to establish a reference range for values of pro-inflammatory cytokines (IL-1 $\beta$, IL-4, IL-6 and TNF- $\alpha$ ) and MMPs (MMP-2 and MMP-9) in the synovial fluid of horses of different ages. The old horses group presented higher values of IL- 4 and TNF- $\alpha$ than the rest of the groups studied $(\mathrm{P}<0.001$ vs. all other groups). IL-1 $\beta$ levels were higher in foals than in all the other groups $(\mathrm{P}<0.001)$. No statistically significant differences were found between the groups as regards the mean IL-6 values. Synovial MMP-2 levels were statistically lower in the old horses group $(\mathrm{P}<0.001)$ and higher in the foals group $(\mathrm{P}<0.05)$. Higher MMP-9 levels were found in the foals group ( $55.45 \pm 58.1$ percentage of proteolysis) $(\mathrm{P}<0.001 \mathrm{vs}$. all other groups). This study demonstrates the existence of variations in the levels of pro-inflammatory markers in the synovial fluid of horses at different ages.

Key words: matrix metalloproteinase; cytokines; osteoarthritis; synovial markers

\footnotetext{
*Corresponding author:

Emilio Adrián De Simone, PhD, Buenos Aires University, School of Veterinary Science, Animal Physiology, Buenos Aires, Av. Chorroarín 280 - (C1427CWO), Buenos Aires, Argentina, Phone/Fax: +54 114524 8456; E-mail: edesimone@fvet.uba.ar
} 


\section{Introduction}

Osteoarthritis (OA) is one of the most common chronic inflammatory diseases in horses. OA is characterized by the slow progressive degeneration of the articular cartilage, subchondral bone alteration and variable secondary synovial inflammation. The clinical presentation of OA is characterized by joint pain and biomechanical failure. OA has a significant economic impact on the horse racing business since it is the most frequent cause of early retirement from competition due to recurring temporary or permanent pain (KIDD et al., 2001).

The articular cartilage is the most seriously damaged tissue in OA. The cartilage is avascular in adults, and for this reason it does not have the regenerative capacity of other tissues. During inflammatory processes, chondrocytes have been found to express several catabolic factors, such as matrix metalloproteinases (MMPs), nitric oxide and cytokines, which contribute to increasing the damage and pain in the affected joint (ATTUR et al., 2002; BERENBAUM, 2013; LI et al., 2015). This damage is characterized by an initial loss of proteoglycans from the upper zone, followed by degradation of the collagen network and inhibition of glycosaminoglycans incorporation. In turn, the resulting inflammatory process also causes sclerosis of the subchondral bone by increasing its catabolic process activity (HULEJOVA et al., 2007). Studies performed in the carpal bone of racehorses have revealed progressive degenerative changes in the articular cartilage and the subchondral bone, including serious focal resorptive lesions (LACOURT et al., 2012).

At different stages of OA, pro-inflammatory cytokines (IL-1 $\beta$, TNF- $\alpha$ and IL-6) are secreted in the synovial fluid by different cell types, such as macrophages, fibroblast-like synoviocytes, osteoclasts, plasma cells, neutrophils, chondrocytes and other joint cells (KAMM et al., 2010; KAPOOR et al., 2011). Biochemical markers offer clinicians a valuable aid to identifying advanced stages of joint disease more accurately. Particularly of interest are markers whose elevation correlates with the presence of specific diseases and that normalize following successful therapy (McILWRAITH, 2005). TNF- $\alpha$ promotes the release of other proinflammatory cytokines (BAKER et al., 2011), and stimulates the secretion of proteases (HAN et al, 2001), leukotrienes (YUDINA et al., 2008), histamine (LIAO and HSIEH., 1992) and prostaglandins (IWABUCHI et al., 2008). In addition, IL$1 \beta$ and TNF- $\alpha$ inhibit chondrogenesis and extracellular matrix synthesis (WEHLING et al., 2009), and are thus crucial in the progression of OA.

The synovial concentration of TNF- $\alpha$ in racehorses seems to increase after 3 years from the beginning of training (BERTUGLIA et al., 2016).

MMPs are a family of calcium- and zinc-dependent proteases acting on the extracellular matrix proteoglycan, gelatin, fibronectin, laminin and aggrecan, which is the major proteoglycan in cartilage, during physiological and pathological processes 
(HADLER-OLSEN et al., 2011). The degradation of the extracellular matrix results in the destruction of the articular cartilage and the subchondral bone (GALASSO et al., 2012). MMPs involved in OA are known to participate in processes such as the physiological development, regeneration and active phase of arthritis.

The gelatinases MMP-2 and MMP-9 act on the degradation products of collagen. Such degradation products modulate the expression of MMPs, promoting the conversion of pro-MMP-2 into active MMP-2 (FICHTER et al., 2005). The biomarkers associated with the degradation of type II collagen can be considered promising molecules to evaluate the activity of proteases in OA (FAWZI et al., 2017; OESTERGAARD et al., 2006). Likewise, there is a correlation between articular cartilage damage and synovial fluid bone alkaline phosphatase and keratan sulphate, which validates their potential use as diagnostic tools in equines (FULLER et al., 2001).

Osteoarthritis is usually confirmed when symptoms are severe, including painful joint episodes, alternating with periods of remission. Severe symptoms tend to occur in the radiographically more advanced stages of the disease, when palliation is more difficult to accomplish. X-ray imaging may be normal in the early stages of the disease, becoming abnormal in advanced stages (KIDD et al., 2001). The aim of this study was to determine the normal values for pro-inflammatory cytokines and MMPs in the synovial fluid of healthy horses of different ages. These reference values could be useful for diagnosis of $\mathrm{OA}$ at an early stage, when the radiological changes are not evident. Besides, these biomarkers could be used for evaluation of the patient's response to treatment. These 'biomolecular markers' could be useful in the early detection of OA. Early detection is very important for disease prevention and clinical treatment planning. A deeper understanding about the fluctuations of these biomarkers could make it possible to implement individualized therapies in the future (BERTUGLIA et al., 2016).

\section{Materials and methods}

Animals and samples. The horses were divided into four groups according to age: i) foals from 1.5 to 3 years $(n=21)$, ii) adult horses from 4 to 9 years $(n=23)$ iii) adult horses from 9 to15 years $(n=25)$, and iv) old horses $\geq 16$ years $(n=22)$. Their clinical condition was evaluated by a global score, comprising six items: (1) lameness degree, (2) tenderness, (3) presence of pain under forced flexion, (4) volume of synovial fluid extracted, (5) color of synovial fluid and (6) synovial fluid viscosity. All the parameters evaluated were those of healthy animals. The global score had been previously employed (DE SIMONE et al., 2015b). Synovial fluid samples were taken using strict aseptic techniques by arthrocentesis of the tibiotarsal joint of 91 clinically healthy jumping horses, with no prior history of lameness or joint disease. A sample was taken from the right tibiotarsal joint of each animal. This joint is a site of high OA prevalence in jumping 
horses (McILWRAITH et al., 2012). The study was carried out in accordance with the institutional guidelines regarding the handling of animals for experiments.

Gelatin zymography in synovial fluid for determination of MMP-2 and MMP-9 activities. Gelatin zymography is based on the proteolytic degradation of a natural protein substrate. Ten percent acrylamide gels were prepared according to GRUBER et al (1996). Briefly, acrylamide gels were prepared with pork skin gelatin (Sigma) ( $2 \mathrm{mg} / \mathrm{mL}$ per gel) and $0.1 \%$ SDS. Before loading, $3 \mu \mathrm{L}$ of each sample was dissolved by heating in sample buffer for $5 \mathrm{~min}$ at $95^{\circ} \mathrm{C}$. After electrophoresis, the gels were washed twice with $50 \mathrm{mM}$ Tris, $5 \mathrm{mM} \mathrm{CaCl}_{2}, 150 \mathrm{mM} \mathrm{NaCl} \mathrm{pH} \mathrm{7.5}$, and 2.5\% Triton X-100, at room temperature for $45 \mathrm{~min}$. The gels were then incubated for $24 \mathrm{~h}$ at $37^{\circ} \mathrm{C}$ with a solution containing $50 \mathrm{mM}$ Tris, $0.150 \mathrm{mM} \mathrm{NaCl}, 10 \mathrm{mM} \mathrm{CaCl}_{2}, 1 \mu \mathrm{M} \mathrm{ZnCl}_{2}$, and $0.1 \%$ Triton X-100, pH 7.5. The gels were then stained with a solution of $0.25 \%(\mathrm{w} / \mathrm{v})$ Coomassie Brilliant Blue R-250 in methanol: water: acetic acid (5:1:5). Gel destaining was carried out using 7.5\% (v/v) acetic acid and 20\% (v/v) methanol for $3 \mathrm{~h}$. Gelatinolytic activity was detected by the presence of negative staining due to degradation of gelatin caused by the MMPs present in the synovial fluid sample. The quantification of MMP activity bands was performed with Image J software (National Institute of Health, MD). The MMP activity was expressed as a percentage of proteolysis in respect a control that saturated densitometry in a $50 \%$ and data corresponding to different gels were standardized using internal control samples.

ELISA of IL-1 $\beta, I L-4, I L-6$ and TNF- $\alpha$. The cytokine concentration (IL-1 $\beta$, IL-4, IL$6, \mathrm{TNF}-\alpha ; \mathrm{pg} / \mathrm{mL})$ in the synovial fluid was determined with commercial ELISA kits (OptEIA BD Biosciences, San Diego, CA) according to the manufacturer's instructions. Plates were read at $450 \mathrm{~nm}$ in a Rayto 2100C microplate reader (Rayto Corporation, China). Cytokine concentrations were derived from a standard curve. Each sample was assayed in duplicate.

Statistical analysis. Data were expressed as mean \pm standard deviation. Comparisons were performed by means of nonparametric analysis of variance (Kruskal-Wallis test) followed by Dunn's post hoc test. Significant differences were indicated as $* \mathrm{P}<0.05$, $* * \mathrm{P}<0.01$, and $* * * \mathrm{P}<0.001$. The statistical analysis was performed with the Instat Software package (GraphPad Software, Inc., San Diego, CA).

\section{Results}

The analysis showed that foals and old horses had differences in some of the variable measurements (Table 1). Moreover, IL-1 $\beta$ levels in foals were higher than in the other groups of animals $(\mathrm{P}<0.001)$. The levels of all cytokines, except for IL-6, and both MMPs were found to be significantly different between foals and old horses, $\left({ }^{a} \mathrm{P}<0.001\right)$. In old horses, MMP-2 showed a slight decrease $(\mathrm{P}<0.001$ vs. all other groups), while IL-6 
and MMP-9 remained at medium values. Moreover, the old horses group showed higher values of IL-4 and TNF- $\alpha(\mathrm{P}<0.001 v s$. all other groups).

IL-1 $\beta$ levels in foals were higher than in all other groups $(\mathrm{P}<0.001)$. For the mean IL-6 value, no statistically significant differences were found between the groups (Table 1).

Table 1. IL-1 $\beta$, IL-4, IL-6, TNF- $\alpha$ and MMPs levels in horse synovial fluid. Cytokine values $(\mathrm{pg} / \mathrm{mL})$ are expressed as mean $\pm \mathrm{SD}$. MMP-2 and MMP-9 are expressed in $\%$ of internal control standard.

\begin{tabular}{|l|c|c|c|c|}
\hline \multicolumn{1}{c|}{ Age } & $\begin{array}{c}\text { Foals } \\
1.5-3 \text { years } \\
\text { Cytokines }\end{array}$ & $\begin{array}{c}\text { Adults } \\
4-9 \text { years } \\
\mathrm{n}=21\end{array}$ & $\begin{array}{c}\text { Adults } \\
10-15 \text { years } \\
\mathrm{n}=25\end{array}$ & $\begin{array}{c}\text { Old } \\
\geq 16 \text { years } \\
\mathrm{n}=22\end{array}$ \\
\hline IL-1 $\beta$ & $120.96 \pm 42.49^{\mathrm{a}}$ & $55.74 \pm 9.09$ & $81.46 \pm 38.08^{\mathrm{b}}$ & $57.12 \pm 8.38$ \\
Lower 95\% CI & 101.62 & 50.77 & 65.74 & 53.40 \\
Upper 95\% CI & 140.30 & 59.72 & 97.18 & 60.84 \\
\hline IL-4 & $6.10 \pm 1.43$ & $5.92 \pm 2.24$ & $4.62 \pm 2.29$ & $10.83 \pm 4.20^{\mathrm{a}}$ \\
Lower 95\% CI & 5.45 & 4.96 & 3.43 & 8.97 \\
Upper 95\% CI & 6.75 & 6.89 & 5.79 & 12.69 \\
\hline IL-6 & $115.14 \pm 52.49$ & $148.82 \pm 56.69$ & $110.66 \pm 47.11$ & $134.21 \pm 45.24$ \\
Lower 95\% CI & 91.25 & 125.42 & 87.23 & 114.15 \\
Upper 95\% CI & 139.03 & 172.22 & 134.09 & 154.27 \\
\hline TNF- $\alpha$ & $41.42 \pm 13.64$ & $36.81 \pm 7.58$ & $33.14 \pm 7.39$ & $86.35 \pm 43.25^{\mathrm{a}}$ \\
Lower 95\% CI & 35.21 & 33.68 & 29.57 & 67.17 \\
Upper 95\% CI & 47.63 & 39.94 & 36.70 & 105.53 \\
\hline MMP-2 & $140.47 \pm 61.98^{\mathrm{c}}$ & $101.45 \pm 44.84$ & $117.29 \pm 55.31$ & $49.13 \pm 18.50^{\mathrm{a}}$ \\
Lower 95\% CI & 112.26 & 84.71 & 95.40 & 40.93 \\
Upper 95\% CI & 168.68 & 118.19 & 139.17 & 57.33 \\
\hline MMP-9 & $55.45 \pm 58.17^{\mathrm{a}}$ & $2.32 \pm 4.55$ & $13.04 \pm 16.46$ & $8.28 \pm 7.63$ \\
Lower 95\% CI & 28.97 & 0.24 & 5.34 & 4.89 \\
Upper 95\% CI & 81.93 & 4.39 & 20.74 & 11.66 \\
\hline
\end{tabular}

${ }^{\mathrm{a}} \mathrm{P}<0.001 v$ s. all other groups, ${ }^{\mathrm{b}} \mathrm{P}<0.05$ vs. adults $4-9$ years and old group, ${ }^{\mathrm{c}} \mathrm{P}<0.05$ vs. adults $4-9$ years old group

Synovial MMP-2 levels (\% of internal control) were statistically lower in the old horses group $(\mathrm{P}<0.001)$ and higher in the foals group $(\mathrm{P}<0.05)$ as compared to the rest of the groups.

Higher MMP-9 levels were found in the foals group $(55.45 \% \pm 58.17)(\mathrm{P}<0.001$ vs. all other groups). 
M. A. Chiappe Barbará et al.: Inflammatory values in synovial fluid of horses
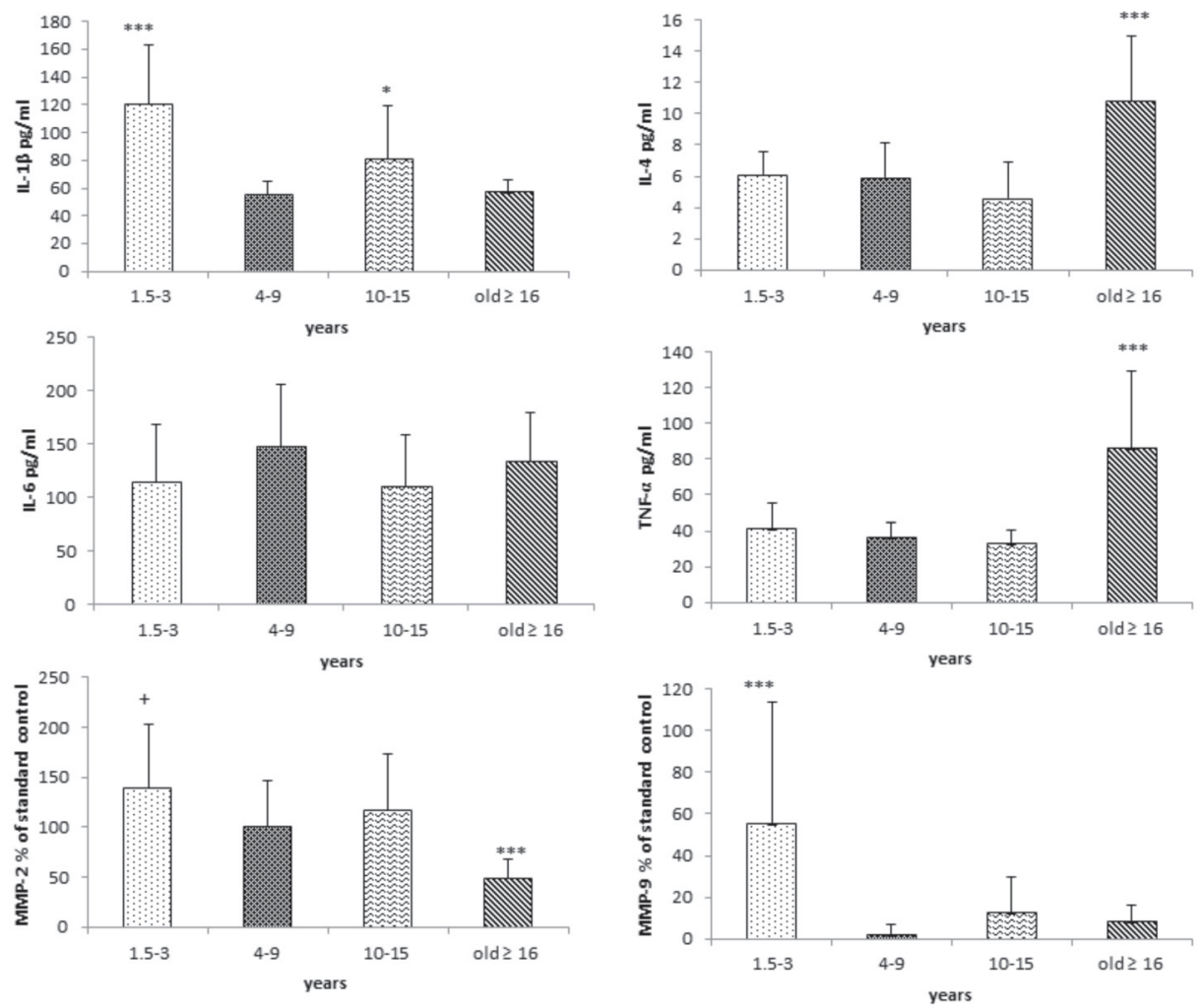

Fig. 1. IL-1 $\beta$, IL-4, IL-6, TNF- $\alpha$, and MMPs levels in synovial fluid obtained from horses. Cytokine values $(\mathrm{pg} / \mathrm{mL})$ are expressed as mean \pm SD. MMP-2 and MMP-9 are expressed as a \% of the internal control standard. *** $\mathrm{P}<0.001$ vs. all other groups, $* \mathrm{P}<0.05$ vs. $4-9$ years adult and old age group. ${ }^{+} \mathrm{P}<0.01$ vs. $4-9$ years adult.

\section{Discussion}

The results obtained in this study indicate that foals and old horses present different behavior as regards the biomarkers studied. Thus, the levels of IL- $1 \beta$ and MMP-9 were found to be higher in foals, while TNF- $\alpha$ and IL- 4 were higher in old horses. The variations in the levels of these biomarkers have physiological implications, as has already been described for other tissues (ARTHUR, 2000).

Additionally, the determination of a reference range of values for cytokines and MMPs in synovial fluid allows us to acquire deeper insight into the pathophysiology 
of OA. Cytokines were analyzed in the synovial fluid because it has previously been demonstrated that this biological fluid is more suitable than serum for diagnosing and evaluating the course of OA in horses (HULEJOVA et al., 2007).

The IL-6 values found were comparable to those obtained by GALLELLI et al., 2013; who measured IL-6 levels in synovial fluid from OA patients receiving different therapies. Plasma IL-6 could increase with muscular exercise (ULLUM et al., 1985). The values obtained by GALLELLI et al. ranged from 50 to $350 \mathrm{pg} / \mathrm{mL}$, and are similar to the values obtained in this study. Both TNF- $\alpha$ and IL- $1 \beta$ are potent inducers for the synthesis of IL-6. Furthermore, high levels of IL-6 produce negative feedback on TNF- $\alpha$ and IL$1 \beta$. Consequently, IL-6 might play either an anti-inflammatory or a pro-inflammatory role (MORLEY and BAUMGARTNER, 2004). In bone, IL-6 is synthesized by osteoblasts and osteoclasts, promoting bone resorption. In advanced forms of $\mathrm{OA}$, the subchondral bone is known to contain increased IL-6 levels. Besides, the high levels of IL-6 found in foals could be explained as a result of the physiological remodeling entailed by the growth process. Furthermore, testosterone is known to inhibit the secretion of IL-6 by bones, therefore, as testosterone declines with age, old animals are expected to present higher levels of IL-6 (HOLBAUER et al., 1994). Moreover, parathyroid hormone levels rise with age, thus increasing the production of IL-6 by osteoblasts (GREY et al., 1996). IL-6 induces an increase in cortisol, leading to neutrocytosis and late lymphopenia. These elevated cortisol levels are comparable to those achieved during exercise, suggesting that muscle-derived IL-6 has a central role in exercise-induced leukocyte trafficking (STEENSBERG et al., 2003).

High IL-1 $\beta(\mathrm{P} \leq 0.001)$ values were found in the synovial fluid of foals. This proinflammatory cytokine induces the release of TNF- $\alpha$ and IL- 6 by activated T cells. Even though the role of this cytokine in bone remodeling under physiological conditions remains unknown, IL-1 is believed to regulate bone metabolism through the upregulation of osteoclast formation involved in normal bone growth during the early stages of skeletal development (LEE et al., 2010). IL-1 $\beta$ also activates nuclear factor kappa B to produce its effects at the nuclear level (MORLEY and BAUMGARTNER, 2004). In addition, IL-1 $\beta$ is involved in the process of the degradation of the extracellular matrix in articular cartilage, especially if mechanical overload is present (TORZILLI et al., 2010).

The induction of IL-4 synthesis in horses with experimental arthritis could have a protective effect on bone and cartilage. It has been described that IL-4 prevents joint damage and bone erosion in the knees of mice with induced collagen arthritis (CIA) (LUBBERTS et al., 2000). The high IL-4 values found in the group of old horses over 15 years of age could be associated with this effect.

High levels of TNF- $\alpha$ in joint fluid has proved to be an important indicator of inflammation. In OA, high values of TNF- $\alpha$ are observed in synovial fluid, though this 
increase does not always occur systemically. In addition, TNF- $\alpha$ is particularly high in the synovial fluid in infectious arthritis (JENG et al., 1997). In our study, the highest values of TNF- $\alpha$ were found in the group of old horses over 16 years of age. TNF- $\alpha$ participates in the activation of collagenases. In aged horses, the increased activity of interstitial collagenases such as MMP-1 is observed (KAMM et al., 2010). In this study, TNF- $\alpha$ values were, in all cases, higher than those reported by GALLELLI et al, (2013) for OA human patients, as values reported by this author did not exceed $3 \mathrm{pg} / \mathrm{mL}$, whereas, in our study, the lowest mean value was $\sim 30 \mathrm{pg} / \mathrm{mL}$.

Healthy foals also presented high levels of MMP-9, which could be related to intense bone growth.

It has been described previously that MMP-9 plays an important role in bone remodeling, participating in the regulation of growth plate activity (VU et al., 1998). The latter phenomenon could explain the higher levels of MMP-9 found in young horses, as compared to adults. In adult horses, the MMP-9 level is generally high when there is a degenerative inflammatory process (FIETZ et al., 2008). In previous studies, similar values were obtained in horses treated with anti-TNF- $\alpha$ (DE SIMONE et al., 2015a). The antiTNF- $\alpha$ therapy was found to improve the clinical score and joint molecular biomarkers of treated horses. The improvement was sustained throughout the experimental period (60 days) (DE SIMONE et al., 2015 a).

In summary, in this paper we determined the mean values of some cytokines and MMPs in a large group of synovial fluid samples obtained from healthy horses, belonging to different age groups. It may be concluded that measurement of these molecular biomarkers may be very useful for diagnosis and selection of treatment for horses with joint disease. We observed that young and elderly horses present different biomarkers profiles.

\section{Acknowledgements}

This work was supported by grant UBACyT 20020120100092BA.

\section{Conflicts of interest}

The authors declare that they have no conflict of interest in the research.

\section{References}

ARTHUR. M. (2000): Fibrogenesis II. Metalloproteinases and their inhibitors in liver fibrosis. Am. J. Physiol. 279, 245-249.

ATTUR, M. G., M. DAVE, M. AKAMATSU, M. KATOH, A. R. AMIN (2002): Osteoarthritis or osteoarthrosis: the definition of inflammation becomes a semantic issue in the genomic era of molecular medicine. Osteoarthr. Cartil. 10, 1-4. 
M. A. Chiappe Barbará et al.: Inflammatory values in synovial fluid of horses

BAKER, R. G., M. S. HAYDEN, S. GHOSH (2011): NF-kappaB, Inflammation, and Metabolic Disease. Cell. Metab. 13, 11-22.

BERENBAUM, F. (2013): Osteoarthritis as an inflammatory disease (osteoarthritis is not osteoarthrosis!). Osteoarthr. Cartil. 21, 16-21.

BERTUGLIA, A., E. PAGLIARA, E. GREGO, A. RICCI, N. BRKLJACA-BOTTEGARO (2016): Pro-inflammatory cytokines and structural biomarkers are effective to categorize osteoarthritis phenotype and progression in Standardbred racehorses over five years of racing career. BMC Vet. Res. 12, 246.

DE SIMONE, E., G. PERRONE, N. CAGGIANO, Y. LASTRA, F. RUBATINO, A. FERRETTO, J. DIAZ, M. A. CHIAPPE BARBARÁ (2015a): Analysis of the therapeutic use of anti -TNF -alpha in three horses with chronic osteoarthritis Vet. Arg. 32, 1-10 (in Spanish).

DE SIMONE, E., G. PERrone, N. CAGGIANO, Y. LASTRA, F. RUBATINO, J. DÍAZ, A. FERRETTO, C. MONTES DE OCA, E. ROLDÁN, M. CHIAPPE BARBARÁ (2015b): Levels of Cytokines and Matrix Metalloproteinases 2 and 9 in the Synovial Fluid of Osteoarthritic Horses Treated With Pamidronate. J. Eq. Vet. Sci. 35, 577-583.

FAWZY, R., N. HASHAAD, A. MANSOUR (2017): Decrease of serum biomarker of type II Collagen degradation (Coll2-1) by intra-articular injection of an autologous plasma-richplatelet in patients with unilateral primary knee osteoarthritis. Eur. J. Rheumatol. 4, 93-97.

FICHTER, M., U. KÖRNER, J. SCHÖMBURG, L. JENNINGS, A. A. COLE, J. MOLLENHAUER (2005): Collagen degradation products modulate matrix metalloproteinase expression in cultured articular chondrocytes. J. Orthop. Res. 24, 63-70.

FIETZ, R., R. ENISPANIER, S. HOPPNER, B. HERTSCH, A. BONDZIO (2008): Determination of MMP-2 and -9 activities in synovial fluid of horses with osteoarthritic and arthritic joint diseases using gelatin zymography and immunocapture activity assays. Equine Vet. J. 40, 266271.

FULLER, C. J., A. R. BARR, M. SHARIF, P. A. DIEPPE (2001): Cross-sectional comparison of synovial fluid biochemical markers in equine osteoarthritis and the correlation of these markers with articular cartilage damage. Osteoarthr. Cartil. 9, 49-55.

GALASSO, O., F. FAMILIARI, M. DE GORI, G. GASPARINI (2012): Recent findings on the role of gelatinases (matrix metalloproteinase-2 and -9) in osteoarthritis. Adv. Orthop. Article ID 834208.

GALLELLI, L., O. GALASSO, D. FALCONE, S. SOUTHWORTH, M. GRECO, V. VENTURA, P. ROMUALDI, A. CORIGLIANO, R. TERRACCIANO, R. SAVINO, E. GULLETTA, G. GASPARINI, G. DE SARRO (2013): The effects of nonsteroidal anti-inflammatory drugs on clinical outcomes, synovial fluid cytokine concentration and signal transduction pathways in knee osteoarthritis. A randomized open label trial. Osteoarthr. Cartil. 21, 1400-1408.

GREY, A., M. A. MITNICK, S. SHAPSES, A. ELLISON, C. GUNDBERG, K. INSOGNA (1996): Circulating levels of interleukin-6 and tumor necrosis factor-alpha are elevated in primary hyperparathyroidism and correlate with markers of bone resorption. J. Clin. Endocrinol. Metab. 81, 3450-3454. 
GRUBER, B. L., D. SORBI, D. L. FRENCH, M. J. MARCHESE, G. J. NUOVO, R. R. KEW, L. ARBEIT (1996): Markedly elevated serum MMP-9 (gelatinase B) levels in rheumatoid arthritis: a potentially useful laboratory marker. Clin. Immunol. Immunopathol. 78, 161-171.

HADLER-OLSEN, E., B. FADNES, I. SYLTE, L. UHLIN-HANSEN, J. O. WINBERG (2011): Regulation of matrix metalloproteinase activity in health and disease. FEBS J. 278, 28-45.

HAN, Y. P., T. L. TUAN, M. HUGHES, H. WU, W. L. GARNER (2001): Transforming growth factor-beta and tumor necrosis factor-alpha mediated induction and proteolytic activation of MMP-9 in human skin. J. Biol. Chem. 276, 22341-22350.

HOLBAUER, L. C., R. M. TEN, S. KHOSLA (1999): The anti-androgen hydroxyflutamide and androgens inhibit interleukin-6 production by an androgenresponsive human osteoblastic cell line. J. Bone Miner. Res. 14, 1330-1337.

HULEJOVA, H., V. BARESOVA, Z. KLEZL, M. POLANSKA, M. ADAM, L. SENOLT (2007): Increased level of cytokines and matrix metalloproteinases in osteoarthritic subchondral bone. Cytokine 38, 151-156.

IWABUCHI, S., M. ITO, T. CHIKANISHI, Y. AZUMA, H. HARO (2008): Role of the tumor necrosis factor-alpha, cyclooxygenase-2, prostaglandin E2, and effect of low-intensity pulsed ultrasound in an In vitro herniated disc resorption model. J. Orthop. Res. 26, 1274-1278.

JENG, G. W., C. R. WANG, S. T. LIU, C. C. SU, R. T. TSAI, T. S. YEH, C. L. WEN, Y. Q. WU, C. Y. LIN, G. L. LEE, M. Y. CHEN, M. F. LIU, C. Y. CHUANG, C. Y. CHEN (1997): Measurement of synovial tumor necrosis factor-alpha in diagnosing emergency patients with bacterial arthritis. Am. J. Emerg. Med. 15, 626-629.

KAMM, J. L., A. J. NIXON, T. H. WITTE (2010): Cytokine and catabolic enzyme expression in synovium, synovial fluid and articular cartilage of naturally osteoarthritic equine carpi. Equine Vet. J. 42, 693-699.

KAPOOR, M., J. MARTEL-PELletier, D. LAJEUNESSE, J. P. PELLETIER, H. FAHMI (2011): Role of proinflammatory cytokines in the pathophysiology of osteoarthritis. Nature Rev. Rheum. 7, 33-42.

KIDD, J. A., C. FULLER, A. R. S. BARR (2001): Osteoarthritis in the horse. Equine Vet. Educ. $13,160-168$.

LACOURT, M., C. GAO, A. LI, C. GIRARD, G. BEAUCHAMP, J. E. HENDERSON, S. LAVERTY (2012): Relationship between cartilage and subchondral bone lesions in repetitive impact trauma-induced equine osteoarthritis. Osteoarthr. Cartil. 20, 572-583.

LEE, Y. M., N. FUJIKADO, H. MANAKA, H. YASUDA, Y. IWAKURA (2010): IL-1 plays an important role in the bone metabolism under physiological conditions. Int. Immunology 22, 805-816.

LI, H., C. CHEN, S. CHEN (2015): Posttraumatic knee osteoarthritis following anterior cruciate ligament injury: Potential biochemical mediators of degenerative alteration and specific biochemical markers (Reviews). Biomed. Rep. 3, 147-151.

LIAO, T. N., K. H. HSIEH (1992): Characterization of histamine-releasing activity: role of cytokines and IgE heterogeneity. J. Clin. Immunol. 12, 248-258. 
M. A. Chiappe Barbará et al.: Inflammatory values in synovial fluid of horses

LUBBERTS, E., L. A. B JOOSTEN, M. CHABAUD, L. VAN DEN BERSSELAAR, B. OPPERS, C. J. J. COENEN-DE ROO, C. D. RICHARDS, P. MIOSSEC, W. B. VAN DEN BERG (2000): IL-4 gene therapy for collagen arthritis suppresses synovial IL-17 and osteoprotegerin ligand and prevents bone erosion. J. Clin. Invest. 105,1697-1710.

McILWRAITH, C. W (2005): Use of synovial fluid and serum biomarkers in equine bone and joint disease. Equine Vet. J. 37, 473-482.

McILWRAITH, C. W., D. D. FRISBIE, C. E. KAWCAK (2012): The horse as a model of naturally occurring osteoarthritis. Bone Joint Res. 1, 297-309.

MORLEY, J. E., R. N. BAUMGARTNER (2004): Cytokine-Related Aging Process. J. Gerontology. 59, 924-929.

OESTERGAARD, S., L. CHOUINARD, N. DOYLE, M. A. KARSDAL, S. Y. SMITH, P. QVIST, L. B. TANKÓ (2006): The utility of measuring C-terminal telopeptides of collagen type II (CTX-II) in serum and synovial fluid samples for estimation of articular cartilage status in experimental models of destructive joint diseases. Osteoarthr. Cartil. 14, 670-679.

STEENSBERG, A., C. FISCHER, C. KELlER, K. MØLlER, B. PEDERSEN (2003): IL-6 enhances plasma IL-1ra, IL-10, and cortisol in humans. Am. J. Physiol. Endocrinol. Metab. 285, E433-E437.

TORZILLI, P. A., M. BHARGAVA, S. PARK, C. T. CHEN (2010): Mechanical load inhibits IL-1 induced matrix degradation in articular cartilage. Osteoarthr. Cartil. 18, 97-105.

VU, T. H., J. M. SHIPLEY, G. BERGERS, J. E. BERGER, J. A. HELMS, D. HANAHAN, S. D. SHAPIRO, R. M. SENIOR, Z. WERB (1998): MMP-9/Gelatinase B is a key regulator of growth plate angiogenesis and apoptosis of hypertrophic chondrocytes. Cell. 93, 411-422.

WEHLING, N., G. D. PALMER, C. PILAPIL, F. LIU, J. W. WELLS, P. E. MÜLLER, C. H. EVANS, R. M. PORTER (2009): Interleukin-1 and tumor necrosis factor- $\alpha$ inhibit chondrogenesis by human mesenchymal stem cells through NF- $\mathrm{BB}$ dependent pathways. Arthritis Rheum. 60, 801-812.

YUDINA, Y., L. PARHAMIFAR, A. M. BENGTSSON, M. JUHAS, A. SJÖLANDER (2008): Regulation of the eicosanoid pathway by tumour necrosis factor alpha and leukotriene D4 in intestinal epithelial cells. Prostaglandins Leukot. Essent. Fatty Acids 79, 223-231.

Received: 16 February 2017

Accepted: 27 September 2017

CHIAPPE BARBARÁ, M. A., G. PERRONE, N. CAGGIANO, Y. LASTRA, F. RUBATINO, A. FERRETTO, E. A. DE SIMONE: Određivanje referentnih vrijednosti citokina i metaloproteinaza matriksa u sinovijalnoj tekućini konja različite dobi. Vet. arhiv 88, 159-170, 2018.

\section{SAŽETAK}

Osteoartritis (OA) je najčešća bolest zglobova u sportskih konja. Upalni i protuupalni citokini te metaloproteinaze (MMP) imaju ključnu ulogu u degradaciji izvanstaničnog matriksa hrskavice. Istraživanje molekularnih biomarkera upale moglo bi biti korisno u dijagnostici i izboru strategija za liječenje. No, malo se 
M. A. Chiappe Barbará et al.: Inflammatory values in synovial fluid of horses

zna o normalnim vrijednostima upalnih biomarkera u različitoj dobi. Štoviše, rana dijagnoza OA ključna je za osiguranje ranog liječenja, kako bi se spriječilo kronično oštećenje. Cilj ovoga rada bio je utvrditi referentni raspon vrijednosti proupalnih citokina (IL-1 $\beta$, IL-4, IL-6 i TNF-a) i MMP-a (MMP-2 i MMP-9) u sinovijalnoj tekućini konja različite dobi. Skupina starih konja pokazala je veće vrijednosti IL-4 i TNF- $\alpha$ od ostalih istraženih skupina ( $\mathrm{P}<0,001 \mathrm{u}$ odnosu na sve ostale skupine). Razina IL-1 $\beta$ bila je viša u ždrebadi nego u svim ostalim skupinama $(\mathrm{P}<0,001)$. Nije bilo statistički značajne razlike među skupinama u odnosu na prosječne vrijednosti IL-6. Razina MMP-2 u sinoviji bila je statistički niža u skupini starih konja $(\mathrm{P}<0,001)$ i više u skupini ždrebadi $(\mathrm{P}<0,05)$. Visoke razine MMP-9 pronađene su u skupini ždrebadi $(55,45 \pm 58,1 \%$ proteolize $)(\mathrm{P}<0,001$ u odnosu na sve ostale skupine). Ovaj rad pokazuje postojanje varijacija u razinama proupalnih markera u sinovijalnoj tekućini konja različite dobi.

Ključne riječi: metaloproteinaza matriksa; citokini; osteoartritis; markeri; sinovija 